\title{
Path Dependency and the Politics of Socialized Health Care
}

\author{
David Brady \\ University of California, Riverside \\ Susanne Marquardt \\ WZB Berlin Social Science Center \\ Gordon Gauchat \\ University of Wisconsin-Milwaukee \\ Megan M. Reynolds \\ University of Utah
}

\begin{abstract}
Rich democracies exhibit vast cross-national and historical variation in the socialization of health care. Yet, cross-national analyses remain relatively rare in the health policy literature and health care remains relatively neglected in the welfare state literature. We analyze pooled time series models of the public share of total health spending for eighteen rich democracies from 1960 to 2010. Building on path dependency theory, we present a strategy for modeling the relationship between the initial 1960 public share and the current public share. We also examine two contrasting accounts for how the 1960 public share interacts with conventional welfare state predictors: the self-reinforcing hypothesis expecting positive feedbacks and the counteracting hypothesis expecting negative feedbacks. We demonstrate that most of the variation from 1960 to 2010 in the public share can be explained by a country's initial value in 1960. This 1960 value has a large significant effect in models of 19612010, and including the 1960 value alters the coefficients of conventional welfare state predictors. To investigate the mechanism whereby prior social policy influences public opinion about current social policy, we use the 2006 International Social Survey Programme (ISSP). This analysis confirms that the 1960 values predict individual preferences for government spending on health. Returning to the pooled time series, we demonstrate that the 1960 values interact significantly with several conventional welfare state predictors. Some interactions support the self-reinforcing hypothesis, while others support the counteracting hypothesis. Ultimately, this study illustrates how historical legacies of social policy exert substantial influence on the subsequent politics of social policy.
\end{abstract}

Keywords welfare state, rich democracies, public share of health spending, crossnational, path dependency 


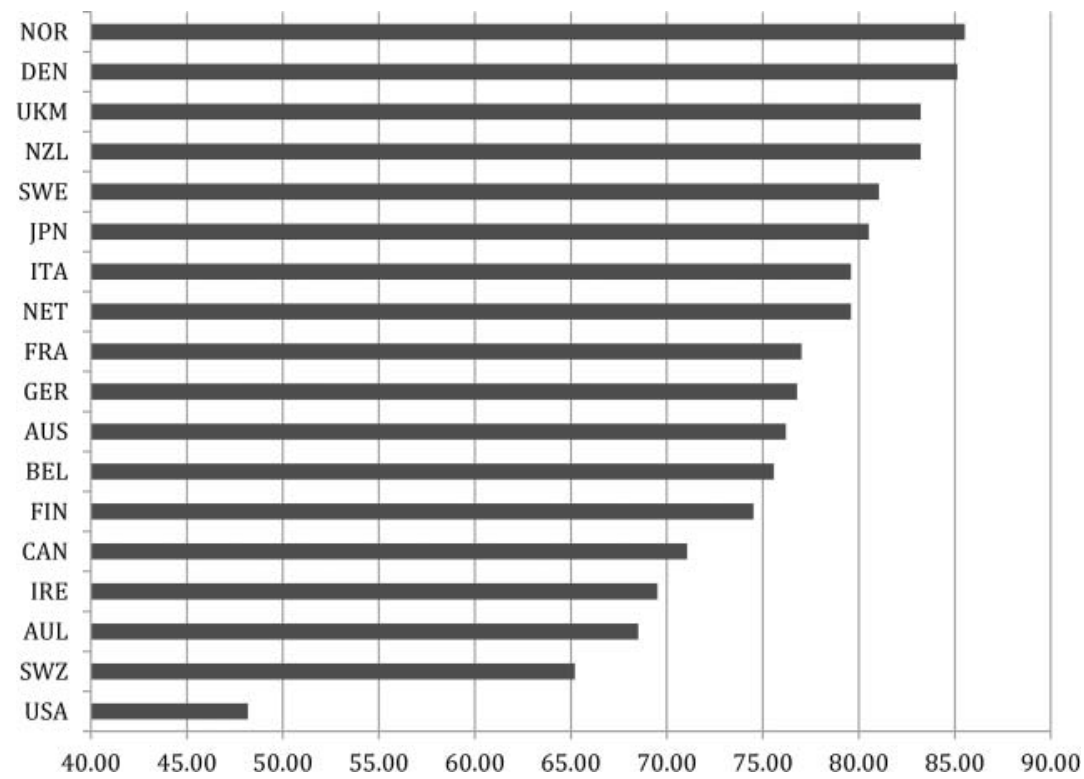

Figure 1 Public Health Spending as a Percentage of Total Health Spending in 2010

There is substantial cross-national variation in the share of total health spending that is publicly financed. Figure 1 displays this "public share" across eighteen rich democracies. In the United States, less than half of total health spending is publicly financed. By contrast, all remaining countries publicly finance at least 65 percent of total health spending. Australia, Ireland, and Switzerland all have public shares at about that level. Even more "socialized" are a diverse set of countries such as Denmark, Japan, New Zealand, Norway, Sweden, and the UK, which publicly finance over 80 percent of total health spending. Finally, for several continental European countries and Canada, the public share is near 75 percent.

The public share does not capture every difference between countries. For example, the public share does not incorporate tax expenditures subsidizing private health insurance / health care and public mandates for insurance, nor does it grasp all differences between health care regimes. Nevertheless, cross-national variation in the public share is important. We conceptualize the public share as one meaningful indicator of the "socialization" of health care, public investments in health and health care, 
and the extent to which the state covers health care costs. The public share reflects policy differences in the organization of health care (Maarse 2006), and is one, while certainly not the only, key manifestation of the underlying differences in institutional regimes (e.g., national health services vs. national insurance systems) (Beckfield, Olafsdottir, and Sosnaud 2013; Wendt 2009). The size of the public share influences health care costs, shapes the organization of insurance, and affects how costs and risks are distributed across the population (Anderson et al. 2003; Jordan 2011; Laugesen and Glied 2011; Morgan and Campbell 2011; Reinhardt, Hussey, and Anderson 2004; Tuohy, Flood, and Stabile 2004; Wilkerson 2003; Wilsford 1995). Public health care is the first or second most expensive social policy in all rich democracies. A greater public share is also associated with lower infant mortality, longer life expectancy (Bambra, Fox, and Scott-Samuel 2005; Beckfield and Krieger 2009; Chung and Muntaner 2006; Navarro et al. 2006; Navarro and Shi 2001), and lower income inequality (Brady 2009; Navarro et al. 2006; Navarro and Shi 2001) (albeit with debates about causality). As illustrated by debates over US health care reform, and market-based reforms in other rich democracies (Bevan, Helderman, and Wilsford 2010; Okma et al. 2010), the public financing of health care is a major source of political contention. Indeed, perceived high government spending on health care is often invoked in public debates about national debt and deficit spending, and in calls for the retrenchment and restructuring of health care policy.

The present study investigates the sources of the cross-national and historical variation in the public share of health care spending. We analyze pooled time series data on eighteen rich democracies from 1960 to 2010. We supplement this with analyses of the 2006 International Social Survey Programme (ISSP). Our broader research question is what explains the cross-national and historical variation in the public share in rich democracies. We present a strategy for modeling the relationship between the initial 1960 values of the public share and the current public share. Building on path dependency theory, we propose the initial 1960 levels capture the historical legacy of prior health care politics and policy. We also examine two contrasting accounts for why the 1960 public share should interact with conventional welfare state predictors: the self-reinforcing hypothesis expecting positive feedbacks and the counteracting hypothesis expecting negative feedbacks. As a result, we investigate how the initial 1960 values interact with other sources to produce contemporary variation in the public share. 


\section{Past Research}

The prevailing approach to studying the sources of public health care is case studies of individual countries or small-N comparisons. In 2005, for example, the Journal of Health Politics, Policy and Law devoted an issue to case studies of European health policy, including articles on eleven countries (e.g., Bevan and Robinson 2005; Rochaix and Wilsford 2005; and Vrangbaek and Christiansen 2005). Case studies of the United States have been especially prominent (Campbell 2011; Daschle, Greenberger, and Lambrew 2008; Jacobs and Skocpol 2012; Morgan and Campbell 2011; Quadagno 2005; Skocpol 1996; Steinmo and Watts 1995). In his classic case study, Starr (1982) documents the role of the professionalization of medicine and the corporatization of insurance for the long-term development of US health care. Among the small-N comparisons (Dutton 2007; Immergut 1992; Okma et al. 2010; Wilsford 1994; Wilsford 1995), Wilsford 1994 compares the development of health policy in France, Germany, the UK, and the United States. From this literature, one can find insightful histories of health policy for nearly all rich democracies.

This literature has clearly made valuable contributions and provides a foundation for our arguments below. However, there has been a relative shortage of cross-national analyses of the public share (Bambra, Fox, and Scott-Samuel 2005; Moran 2000; Olafsdottir and Beckfield 2011). Describing the health policy literature, in the Journal of Health Politics, Policy and Law, Blake and Adolino (2001: 679-80) write:

The literature is dominated by national and comparative case studies. ... The straightforward formulation of a cross-national research problem seems so obvious that it almost defies comment. However, in the public and scholarly debate over health policy dynamics in the United States, one searches in vain for an analysis that encompasses all (or even most) advanced industrial democracies.

In the period since, quantitative cross-national analyses remain relatively rare in the health policy literature and health care remains relatively neglected in the welfare state literature. ${ }^{1}$

1. Echoing Blake and Adolino, Hacker (2004: 693) calls health care a "blind spot" in welfare state research: "Over the past two decades, structural reform of national health policies has dominated the political agendas of advanced industrial welfare states as never before. Yet students of the welfare state-who have intensively examined the post-1970s development of other prominent realms of social policy-have devoted surprisingly little attention to these crucial disputes, leaving the field almost entirely to health policy specialists." 
This shortage of cross-national analysis is notable because the wellstudied US case is quite unusual (see fig. 1). As a result, case studies focusing solely on the United States may be unable to generalize to the broader set of rich democracies (Marmor, Freeman, and Okma 2005). That the United States is unusual is often highlighted by case studies of the United States. Starr (1982: 6) writes: "Hardly anywhere have doctors been as successful as American physicians in resisting national insurance and maintaining a predominantly private and voluntary financing system." In contrast to the United States, Starr explains (1982: 256), "In neither Germany nor even Britain was the idea of compulsory health insurance fundamentally contested when it was originally proposed." Hacker (2002: 187) echoes: "It is not true . . . that doctors in all countries and at all times have been equally hostile to government intervention." Indeed, the puzzle of why and how socialized medicine never happened in the United States has often been the motivating question for such case studies (Oberlander 2003; Quadagno 2005; Steinmo and Watts 1995).

It is important to acknowledge that in recent years some cross-national analyses have emerged (Jensen 2011; Jordan 2011; Kikuzawa, Olafsdottir, and Pescosolido 2008; Maarse 2006; Montanari and Nelson 2014; Wilensky 2002). A few analyze dependent variables that are similar to or related to the public share: public medical insurance coverage, per capita public health spending, or public health spending as a percent of GDP (Navarro 1989; Navarro et al. 2006; Navarro and Shi 2001; Reeves et al. 2014). For example, Blake and Adolino (2001) analyze the adoption of national health insurance programs across countries. A few others append analyses of the public share alongside traditional welfare state measures. For instance, Huber and Stephens $(2001: 76,217)$ evaluate whether power resources theory predicts the public share of health spending similarly to other welfare effort outcomes. Further, scholars have developed comparative typologies of health care systems with parallels to the welfare state regime literature (Bambra 2005; Beckfield, Olafsdottir, and Sosnaud 2013; Moran 2000; Wendt 2009). Despite these contributions, there are still relatively few cross-national analyses of the public share of health spending. Compared to the vast literatures on welfare effort or programs like pensions and unemployment insurance, there is a need for further research.

The shortage of cross-national research on the public share begs the question of whether conventional welfare state models can explain health care policy (Jensen 2011; Olafsdottir and Beckfield 2011). As one example, power resources theory has featured prominently in the welfare state 
literature (Hicks 1999; Huber and Stephens 2001), and indeed, some link leftist parties and labor unions to public health care (Huber and Stephens 2012; Navarro 1989; Navarro et al. 2006; Navarro and Shi 2001). However, others contend that public health care does not simply follow the same political processes as other social policies (Hacker 2002). For instance, Immergut (1992: 6) stresses, "In no case did the politics of national health insurance boil down to partisan conflicts." Though Huber and Stephens (2001: 76) find left party power is significantly associated with the public share in sixteen rich democracies 1960-1985, they find no party effects on the public share in more recent decades (Huber and Stephens 2001: 217). It is also notable that the public share is not very highly correlated with welfare effort (Bambra 2005). Across the eighteen countries in figure 1, the public share correlates only 0.47 with public social welfare expenditures and 0.35 with public and mandatory private social welfare expenditures (as a percent of GDP, Brady, Huber, and Stephens 2014). This is exemplified by the liberal UK regime, which has comparatively meager social welfare transfers, but a high public share and a national health service. Unlike most other social policies, public health spending realistically faces a ceiling as several countries are near 100 percent of total health spending (Hacker 2004). Therefore, ultimately, it remains quite uncertain if conventional welfare state models can explain the public share.

\section{Path Dependency and the Politics of Social Policy}

As a complement to conventional welfare state models, we propose the public share of health spending is heavily shaped by path dependency. At least since the 1990s, path dependency has emerged as a key concept in the politics of social policy and other literatures (Mahoney 2000; North 1990; Pierson 2004). In its most general form, path dependency simply claims the past has a powerful effect on the present. Scholars often invoke Stinchcombe's (1968) concept of "historical causes" whereby some initial conditions generate an outcome, which is then reproduced even without the recurrence of the initial conditions. These historical legacies "lock" countries into certain trajectories and exert inertia on current politics even after a long time lag (Thelen 2004).

The literature has theorized at least six interwoven mechanisms for why social policies are likely to exhibit path dependency (Campbell 2011; Hacker 2002; Rose and Davies 1994; Skocpol 1992). First, social policies create large constituencies with an interest in maintaining programs and benefits (Korpi and Palme 1998). Second, social policies mobilize actors 
and organizations, which gain resources from programs and have a vested stake in the policy. Third, social policies influence normative expectations about social equality and the role of the state in the economy and society (Brady and Bostic 2015). Fourth, social policies function as institutions that make certain subsequent policies and reforms more efficient and therefore likely to be selected and adopted. As Pierson (2004: 35) explains, "Policies, grounded in law and backed by the coercive power of the state, signal to actors what has to be done, what cannot be done, and establish many of the rewards and penalties associated with particular activities." Fifth, largely because of the prior four, the path dependency of social policy constrains politicians from retrenching or removing programs and benefits (Brooks and Manza 2007).

Path dependency is also a strong theme in the case studies of health policy (Béland 2010; Bevan and Robinson 2005; Campbell 2011; Kikuzawa, Olafsdottir, and Pescosolido 2008; Rochaix and Wilsford 2005; Vrangbaek and Christiansen 2005; Wilsford 1994). For example, Dutton (2007) demonstrates that modern French health care policy reflects an incremental evolution from prior health care policies as well as the imprint of deeper historical origins. Starr (1982) stresses how the historical evolution of medical authority cultivated solidarity, organization, and power among medical professionals. This then enabled a stringent defense of a limited public sector, and powerful private medical and insurance industries. Starr (1982: 333) writes, "The distribution of health insurance was a direct outcome of the sort of private system that developed in America." Immergut (1992) identifies several continuities in French, Swedish, and Swiss health care policies, and shows how political bargains and preexisting sickness funds left their mark on subsequent health care legislation. Quadagno (2005) demonstrates how private health care in the United States created powerful stakeholders (e.g., doctors and insurers) who were well-positioned to recurrently block expansions of public health care. Hacker (2002: 61) shows how private health care/insurance drove the politics of public health care, and claims, "Each intermediate step in favor of privatized social welfare approaches increases the probability that future steps will occur in the same direction."

Thus, where there has historically been a legacy of a high public share, constituencies, organizations, vested organizations and actors, expectations, and institutions should all work to maintain that high level. Conversely, where the historic legacy has been of a low public share, the opposite should hold. The historic legacy can be operationalized as the initial observed level of the public share in the period is analyzed. The 
initial level captures the health care politics and policies that historically preceded the period analyzed. Thus, the initial level represents a starting point after health care policy has evolved up to the period studied. This leads to hypothesis 1 :

H1 Initial levels of the public share of health spending are significantly positively associated with current levels.

While path dependency has been a very influential explanation in qualitative historical research, it has not been as widely incorporated in quantitative research. Though proponents have made clear it is amenable to quantitative applications (Pierson 2004: 172-73), few quantitative crossnational studies fully incorporate path dependency. Thus, there is a need for empirical strategies to do so (Page 2006).

One exception is recent cross-national welfare attitudes research. ${ }^{2}$ Several scholars demonstrate how past social policies or institutionalized historical legacies embodied as welfare state regimes are associated with contemporary social policy attitudes (Brooks and Manza 2007; Fernandez and Jaime-Castillo 2013; Jordan 2010; Svallfors 2007). For instance, Kikuzawa et al. (2008) show that a country's health care regime significantly affects individual preferences for greater government spending on health and for government having a responsibility for health care. This literature posits mass opinion as one key mechanism in the path dependency of social policy (Brooks and Manza 2007; Campbell 2011; Fernandez and Jaime-Castillo 2013; Jordan 2010; Morgan and Campbell 2011; Svallfors 2007). The argument applied here would be that prior health policy influences public opinion by creating interests and normative expectations that define what individuals expect from the state in terms of health care (Lynch and Gollust 2010). Public opinion then works to maintain current health policies and constrains public health care retrenchment. This leads to hypothesis 2 :

H2 Initial levels of public health spending are significantly positively associated with contemporary preferences for government spending on health.

2. Another possible exception is pooled time series analyses showing the significant effect of veto points on the welfare state (e.g., Brady and Lee 2014; Huber and Stephens 2001). However, we would argue veto points are better understood as institutional rules constraining policy change, but not really path-dependent characteristics of the policy itself. Veto points thus might be thought of as a reason path dependency happens but not path dependency within a given social policy (Immergut 1992; Steinmo and Watts 1995; Swank 2002). 
Beyond hypotheses 1-2, the initial levels of social policies have the potential to feed back into contemporary politics through two processes. The first process involves initial conditions having a self-reinforcing effect on the current public share (Mahoney 2000). In this process, path dependency scholars emphasize the increasing returns and positive feedback from initial conditions (Campbell 2011). Pierson (2004: 10) stresses the role of "dynamics of self-reinforcing or positive feedback processes in a political system," and writes, "Once a particular path gets established, however, self-reinforcing processes make reversals very difficult." According to prevailing accounts of positive feedback, initial conditions should fuel the long-term reproduction of cross-national differences. As the historical legacy legitimates and cultivates expectations and constituencies, power asymmetries and vested interests should maintain and reproduce variation across health care regimes. This leads us to posit hypothesis 3:

H3 Initial level of public health spending will positively interact with welfare state predictors to accentuate variation.

Partly because scholars often use path dependency to explain stable differences between countries, the majority of the path dependency literature concentrates on self-reinforcing processes and positive feedbacks (cf. Béland 2010; Pierson 2004). As Fernandez and Jaime-Castillo (2013: 806) write, "The positive policy feedback framework has remained dominant in historical institutionalism." For instance, although Huber and Stephens (2001) distinguish between two kinds of path dependencyratchet effects (which only result in positive feedbacks) and policy legacy effects (which can have positive or negative feedbacks) - the ensuing literature has principally concentrated on positive feedbacks. Indeed, Page (2006) criticizes the path dependency literature for conflating path dependence and increasing returns and, hence, obscuring other forms of path dependence.

As a result, we also consider a second counteractive path dependency process. Counteractive processes involve negative feedbacks between initial conditions and the subsequent politics of social policy (Béland 2010; Fernandez and Jaime-Castillo 2013; Weaver 2010). The public share may be vulnerable to negative feedbacks as countries have "grown to limits," facing a ceiling near 100 percent, and any reform thus requires a reduced public share (Flora 1986; Hacker 2004). Social policies often create unanticipated inefficiencies and enable political actors to frame grievances against the policy or its implementation. For example, targeted social policies (vs. universalist) tend to be unpopular, to divide the working 
class, and to generate coalitions between the affluent and middle class against the working class and poor, all of which feed back into the politics of social policy (Brady and Bostic 2015; Korpi and Palme 1998). Moreover, the prevalent homogenizing pressures of budget austerity, rising health care costs, population aging, and the medicalization of disease may combine to force countries to view or frame a high public share as unsustainable (Brady and Lee 2014; Kikuzawa, Olafsdottir, and Pescosolido 2008; Kittel and Obinger 2003; Pierson 2001). Indeed, rising costs and budget pressures have been a central concern for health care policy across rich democracies (Bevan, Helderman, and Wilsford2010; Marmor, Freeman, and Okma 2005; Reeves et al. 2014; Wilsford 1995). As Hacker (2004: 698) explains, "rapid inflation of health spending was usually the largest and most immediate source of budgetary strain for countries facing up to the new fiscal order." These pressures should constrain high public share countries even more than low public share countries, partly because high public share countries approach the ceiling of 100 percent public financing, and, because health care is a larger share of government budgets in high public share countries (Beckfield, Olafsdottir, and Sosnaud 2013; Nixon 1999). Compared to low public share countries, high public share countries are more able to control costs because health care financing is more centralized and the state is relatively more powerful than private actors (Wendt 2015). All of these pressures should contribute to convergence. This leads to hypothesis 4:

H4 Initial level of public health spending will negatively interact with welfare state predictors to produce convergence.

\section{Methods}

The main analyses include eighteen rich democracies (Australia, Austria, Belgium, Canada, Denmark, Finland, France, Germany, Ireland, Italy, Japan, the Netherlands, New Zealand, Norway, Sweden, Switzerland, the United Kingdom, and the United States) from 1960 to 2010 (the last year with complete data). The unit of analysis is the country-year. The proximate source for all variables is the Comparative Welfare States Data Set (CWS; see Brady, Huber, and Stephens 2014). We concentrate on these eighteen countries partly because of data availability, as omitted rich democracies lack consistent data prior to the 1980s (e.g., Greece, Spain, Portugal). The analyses begin in 1960 because that is the first data point available on the public share. We end in 2010 because the CWS ends then 
and many independent variables are not available after that point. Our focus on rich democracies reflects widely held conventions in the welfare state literature (Brady and Lee 2014; Hicks 1999; Kittel and Obinger 2003; Svallfors 2007; Swank 2002). For instance, we follow Huber and Stephens (2001) who require that countries be economically developed, and democratic at least since World War II.

Because of data availability, the panel is slightly unbalanced resulting in 808 country-years. Descriptive statistics and sources are available in appendix A. In supplementary analyses, we examine 2006 ISSP data. We provide details below and in appendix B.

\section{Dependent Variable}

The dependent variable is the public share of health spending, defined as the percent of total health spending that is publicly financed. We utilize the OECD (2012) definitions of health expenditures and public and private. Public funds include those derived from taxation and social security plans; expenditures from federal, state, and local governments; and publicly financed/subsidized investment in health facilities. Private funds include out-of-pocket payments, private insurance, charities, and occupational health care and insurance.

\section{Independent Variables}

The key independent variable is the 1960 value of the public share of health spending. This variable is time invariant within countries.

We begin with a conventional synthetic welfare state model. Closely following the literature, we incorporate a combination of variables including power resources, institutions, economics, and demographics (Brady and Lee 2014; Hicks 1999; Huber and Stephens 2001, 2012; Kittel and Obinger 2003; Svallfors 2007; Swank 2002). Following convention, we lag all independent variables one year. Because of this, the dependent variable is actually modeled 1961-2010. In later analyses, we include interaction effects between the 1960 value and all aforementioned independent variables.

We measure power resources with four variables. Right cabinet is the average percent of cabinet seats for rightist and conservative parties in the past ten years. Left cabinet is the same for leftist and social-democratic parties. Unionization is the net union membership as a percent of employees. Voter turnout is the percent of the electorate that voted in the most recent national election. Institutions are operationalized by the number of 
constitutional veto points. Veto points sum measures of federalism, presidential systems, single-member district-plurality electoral systems, the strength of bicameralism, the frequency of referendums, and judicial review (Brady and Lee 2014; Huber and Stephens 2001). We also include military spending as percent of GDP. We adjust for five economic variables. GDP $p c$ is per capita gross domestic product in real purchasing power parity dollars. Inflation is the annual percent change in the consumer price index. Unemployment is the percent of the total labor force unemployed. Trade openness is the sum of exports and imports over GDP. Deindustrialization is measured as 100 minus the percent of the labor force in manufacturing and agricultural employment. We incorporate demographics by including the share of the population over sixty-four years old and net migration, which is the difference between people leaving and entering the country divided by the overall population. Female labor force participation is the share of working-age women in the labor force. We also adjust for linear time with year $(1961=0,1962=1 \ldots 2010=50)$. In other analyses, we included year fixed effects and the results were consistent. ${ }^{3}$

\section{Analytic Strategy}

Our aim is to model conventional welfare state predictors and the historic legacy or initial levels of the public share (and their interactions). To accomplish this, we need an estimation strategy that allows for a time invariant variable (the 1960 value) and addresses the within-country and over-time structure of the data.

To put our strategy in context, we first explain how we build on two conventional approaches: fixed effects (FE) and lagged dependent variable (LDV) models. A standard FE model can be estimated as:

$$
\mathrm{Y}_{i t}=\beta_{0}+\beta \mathrm{X}_{i t-1}+\beta \mathrm{C}_{\mathrm{i}}+\varepsilon_{i t}
$$

$\mathrm{Y}_{i t}$ is the dependent variable for each country $i$ and year $t . \mathrm{Y}_{i t}$ is a function of a generic constant $\left(\beta_{0}\right)$, a set of lagged country-year variables $\left(\mathrm{X}_{i t-1}\right)$, country dummies $\left(\mathrm{C}_{i}\right)$, and a country-year error term $\left(\varepsilon_{i t}\right)$. The virtues of the FE model are clear and well known. The country dummies control for unobserved time-invariant differences between countries. The model differences each observation from the country-specific mean for each variable, which focuses the analyses on within-country over-time

3. For instance, in table 1 , model 3 , the 1960 value would have a slightly larger coefficient and remain highly significantly positive $(z=10.97)$. 
variation. For our purposes, the FE model has the problem of prohibiting time invariant variables (e.g., the 1960 value) and it is not really feasible to interact the country dummies and independent variables $\left(\mathrm{X}_{i t-1}\right.$ and $\left.\mathrm{C}_{i}\right)$. Also, the FE model is not well suited to the estimation of theoretically salient variables that do not vary much over time (e.g., veto points). Moreover, the country dummies have no theoretical content and thus cannot offer any explanation for why countries differ.

A standard LDV model can be expressed as:

$$
\mathrm{Y}_{i t}=\beta_{0}+\beta \mathrm{Y}_{i t-1}+\beta \mathrm{X}_{i t-1}+\varepsilon_{i t}
$$

This model differs from the FE model by including a lagged value of the dependent variable $\left(\mathrm{Y}_{i t-1}\right)$ as a right-hand side variable, while it does not require country dummies (though one can also include country dummies). This model controls for past values of $\mathrm{Y}$ and allows time-invariant variables. However, this approach only allows the other independent variables $\left(\mathrm{X}_{i t-1}\right)$ to explain the residual short-term change in the dependent variable, and may be biased by strong correlations between $\mathrm{Y}_{i t-1}$ and $\mathrm{X}_{i t-1}$ or strong autocorrelation. Moreover, $\mathrm{Y}_{i t-1}$ typically does not have any more theoretical content than country dummies.

Our approach builds on FE and LDV models, while addressing their limitations in pursuing our aims. Our approach can be expressed as:

$$
\mathrm{Y}_{i t}=\beta_{0}+\beta \mathrm{Y}_{1960}+\beta \mathrm{X}_{i t-1}+\varepsilon_{i t}
$$

$Y_{1960}$ is the country-specific, time-invariant value of $Y$ in 1960. This is the first observed value of $\mathrm{Y}$, and our approach can be called an "initial conditions" model. This is similar to how scholars often control for the baseline value of the dependent variable while using panel models. Like the FE model, our approach controls for a key timeinvariant difference between countries. Like LDV models, our approach adjusts for a lagged value of Y. However, unlike FE and LDV models, $\mathrm{Y}_{1960}$ has theoretical content as it measures the historical and politicaleconomic factors that shaped a country's "initial conditions" of the public share in 1960. Moreover, our approach allows for time-invariant and relatively stable variables like veto points. Further, our approach enables a more clear interpretation of interactions between $\mathrm{Y}_{1960}$ and $\mathrm{X}_{\mathrm{it}-1}$ than an FE model.

To be clear, we do not claim the 1960 value is a "critical juncture." To model the critical juncture, one could model $\mathrm{Y}_{i}$ at a theoretically salient 
time point (e.g., the Great Depression). We do not do so, partly because 1960 is the first data point available for this sample. While the initial 1960 levels capture the historical legacy of prior health care politics and policy up to the period of study, its sources are beyond the scope of the present study.

Our approach is also influenced by techniques to address state dependence (Esarey and DeMeritt 2014; Page 2006). Those techniques often build on LDV models by including $\mathrm{Y}_{i t-1}$ and interactions between $\mathrm{Y}_{i t-1}$ and $\mathrm{X}_{i t-1}$. Our approach is quite similar (see esp. Esarey and DeMeritt 2014). The key distinction is that we measure $\mathrm{Y}$ at the fixed point in time of the first year $\left(\mathrm{Y}_{1960}\right)$. By doing so, we conceptualize countries as differing based on observed initial conditions rather than $\mathrm{Y}_{i t-1}$ or some state dependence. ${ }^{4}$

We appreciate there still could be concerns that $\mathrm{Y}_{1960}$ is highly correlated with $Y_{i t-1}$. Therefore, we conduct sensitivity analyses adjusting for $\mathrm{Y}_{i t-1}$ - combining our approach and an LDV model. There could also be concern that $\mathrm{Y}_{1960}$ conflates "initial conditions" and unobserved timeinvariant country characteristics. While we cannot incorporate country FEs, we conduct sensitivity analyses adjusting for the country-specific mean of the dependent variable $\left(\overline{\mathrm{Y}}_{i}\right)$, which approximates country-fixed effects (i.e., since an FE model differences $Y_{i t}$ from $\bar{Y}_{i}$ ). If there is a robust significant association between $\mathrm{Y}_{i t}$ and $\mathrm{Y}_{1960}$ net of $\mathrm{Y}_{i t-1}$ or $\overline{\mathrm{Y}}_{i}$, this should increase confidence in the results.

Finally, all models use panel-corrected standard errors (OLS-PCSE) and a first-order autocorrelation correction. As robustness checks, we estimated three alternatives: first-differencing all variables (except the 1960 value); an error-correction model; and, a random effects model with a firstorder autocorrelation correction. In all three, the 1960 value remained significant. The results were also consistent when dropping one country or one year at a time. ${ }^{5}$ All these sensitivity analyses are available upon request. 6

4. Of course, the sources of the observed initial conditions in 1960 could be due to some state dependence. However, as we treat the 1960 initial conditions as given, it is beyond the scope of the present study to identify the sources of the 1960 value.

5. For example, if we omit the relatively outlying United States, the 1960 value remains significantly positive across table $1(p<.001)$.

6. Our approach has similarities to Page's (2006: 104): "A process is early path-dependent if the outcome in any subsequent period depends only upon the history up to some period T." Our approach is also similar to Jackson and Kollman's (2012) "sticky" process. However, our approach does not investigate their "stringent" (Jackson and Kollman 2012) definitions of path dependence. For example, we do not evaluate Page's distinction between "phat" and path dependency. Also, we cannot evaluate Jackson and Kollman's (2012) "precise and restrictive" distinction between "equilibrium-dependent" and "sticky" processes. While interesting, these strategies appear to be quite different from the core ideas in the aforementioned theories and literatures on path dependency. Jackson and Kollman (2012: 173) even conclude: "We recognize the strictness of the definition used here; it limits people to calling nearly everything we study [not path dependence]." In contrast, we aim to model the core idea of path dependency, and we would not concede that their strategies provide the only reasonable definitions of path dependency. 


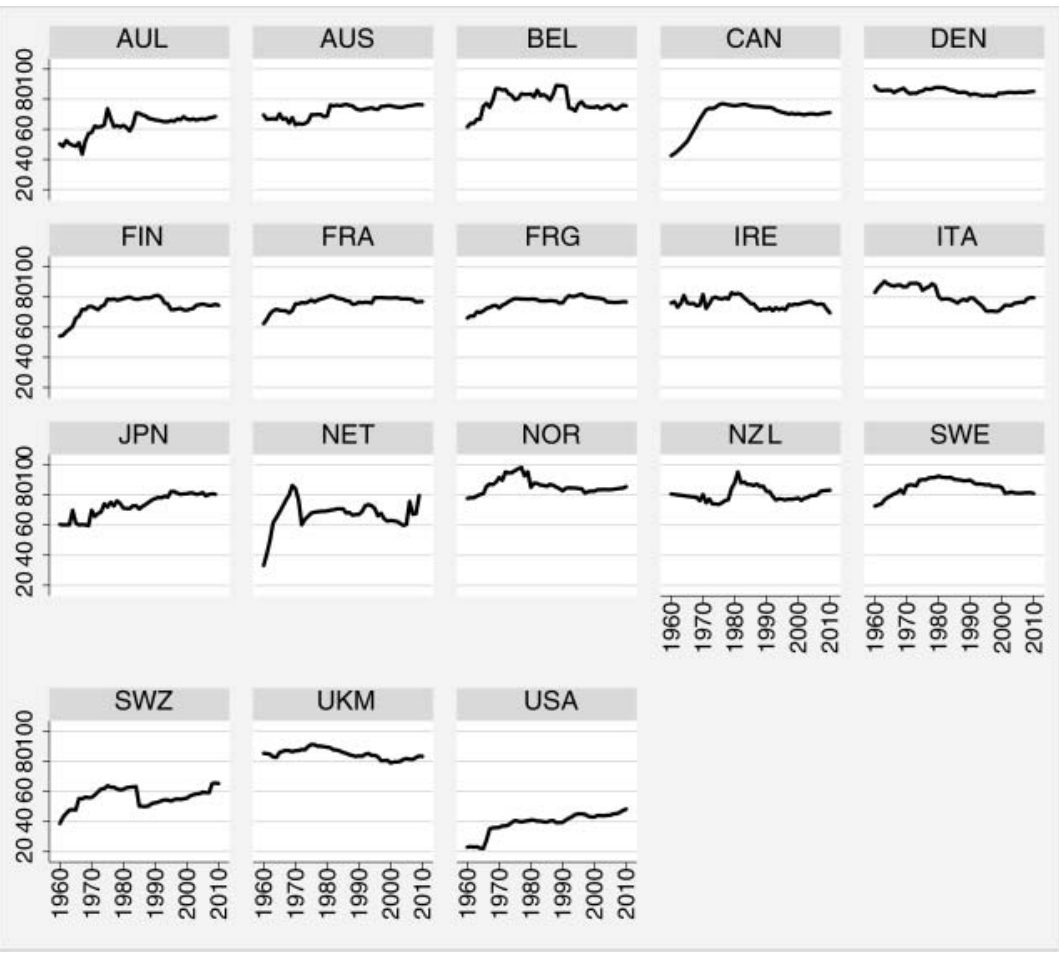

Figure 2 Public Share of Health Spending in Eighteen Rich Democracies, 1960-2010

Notes: In this figure and throughout, the last time-point available for Australia, Japan, and the Netherlands is 2009. For brevity, we simply refer to 2010 as the endpoint.

\section{Results}

\section{Descriptive Patterns}

Figure 2 displays the trends in the public share of health spending for each country. There is substantial historical and cross-national variation with a minimum of 22 percent (United States in 1960) to 98 percent (Norway in 1977). A few countries exhibit sharp breaks (likely reflecting a combination of reforms and measurement error) though the patterns and results are similar if we smooth the trends. The social democratic Nordic countries show consistently high public shares while the liberal United States started and remains relatively low. At the same time, the UK, Australia, and Canada have high public shares despite also being liberal AngloSaxon countries. 


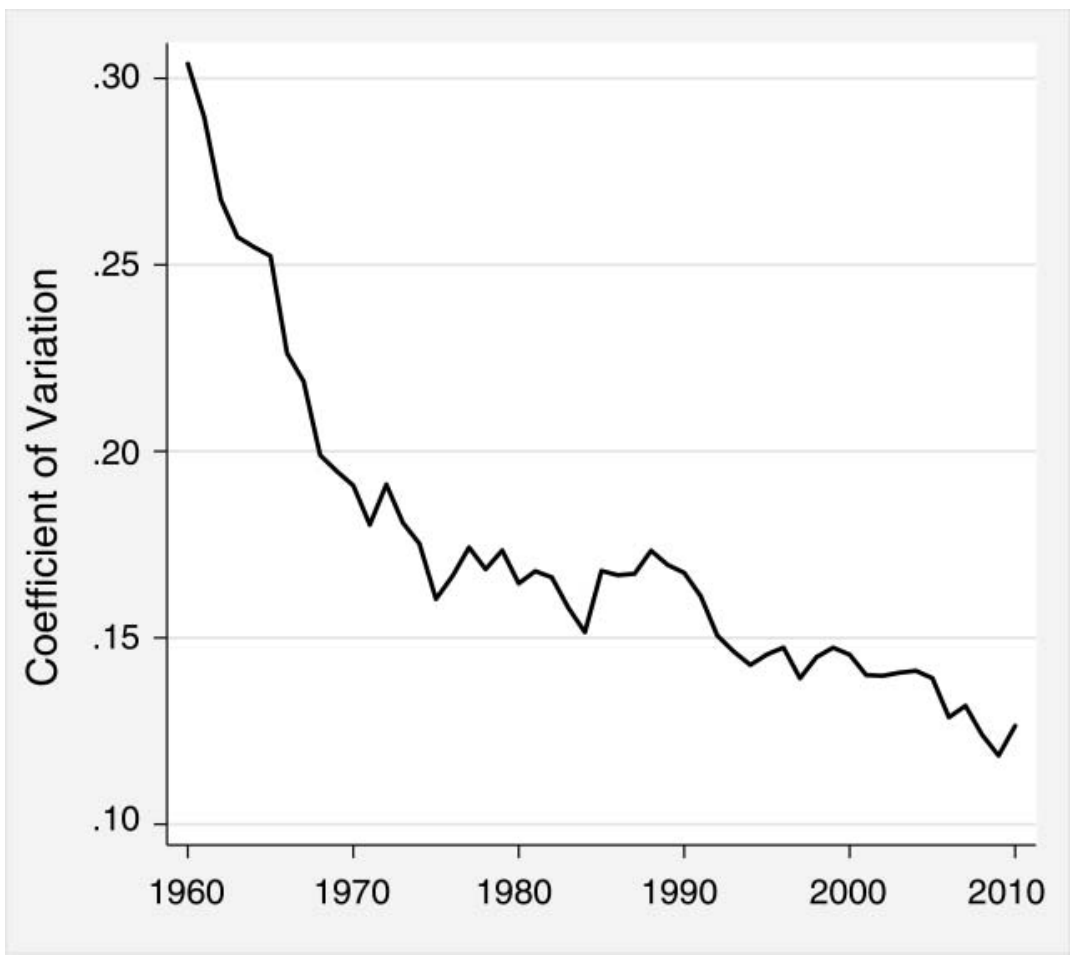

Figure 3 The Coefficient of Variation in the Public Share of Health Spending across Eighteen Rich Democracies, 1960-2010

There is an increase over time in many, but not all, countries. Those with high initial levels in 1960 experienced stagnation or a slight decline, while many countries with low initial levels increased their public share. Across countries, the mean rose from 62.6 in 1960 to 74.7 in 1970. The crossnational mean peaked at 77.3 in 1981 but was actually relatively stable between 1970 and 2010. Indeed, figure 1 reveals that utilizing the 1960 value as the initial condition is probably a conservative choice. 1960 is before many countries experienced substantial expansions in welfare states and health programs, and by 1970, countries had locked into a public share that is much closer to the public share in the 1980s and 1990s (Huber and Stephens 2001).

While there is substantial cross-national and historical variation in the public share, there has also been a significant decline in variation over time (Hacker 2004: 711). Figure 3 reports the annual cross-country coefficient of variation, which provides clear evidence of convergence 


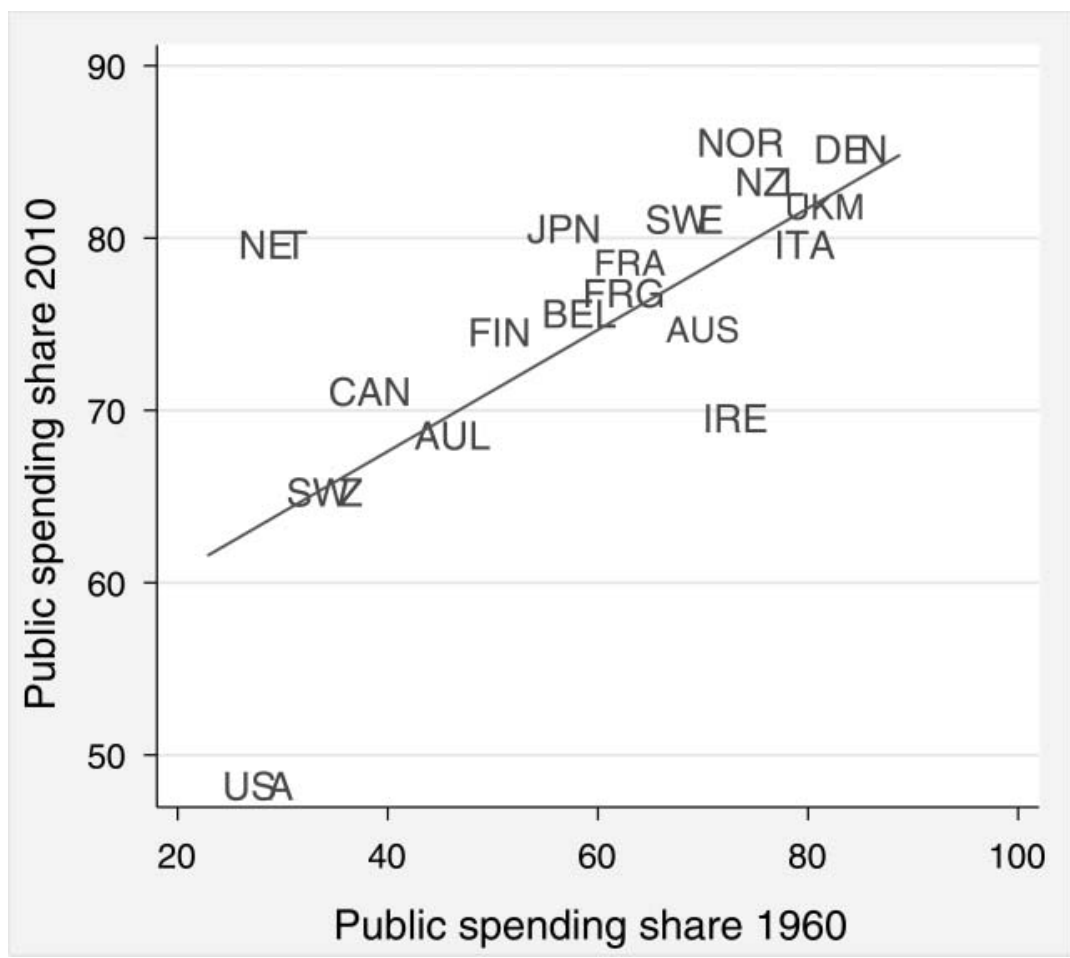

Figure 4 Public Share of Health Spending in 1960 and $2010(r=.749)$

across countries from 1960 to 2010. The coefficient of variation falls from about 0.30 in 1960 to about 0.13 by 2010 . In 1960, the range between the highest and lowest country was 65.73 percent. By 2010, the range declined to 37.7 percent.

Given there has been considerable historical variation mixed with convergence, it might seem unlikely for initial conditions to be strongly associated with current public share. However, figure 4 reveals there is actually a strong correlation between a country's 1960 value and its 2010 public share $(r=0.75)$. There are a few exceptions - e.g., the Netherlands should have a lower public share in 2010 given its 1960 value and the United States should have a higher public share even given its very low public share in 1960. However, the prevailing pattern is a strong association between the 1960 value and the 2010 public share. Thus, despite substantial historical variation and cross-national convergence, there is evidence of a strong path dependency between initial conditions and contemporary variation. 


\section{Main Pooled Time Series Models}

Table 1 displays the models of the public share. To ease comparison, we report standardized coefficients. The first model includes the conventional welfare state predictors but omits the key independent variable of the 1960 value. Consistent with power resources explanations, right cabinet is significantly negative and unionization and voter turnout are significantly positive. Consistent with institutional explanations, veto points is significantly negative and has the largest coefficient of any variable. Among the economic variables, inflation is significantly positive while deindustrialization and trade openness are significantly negative. Among the demographic variables, only population aging is significant $(+)$. Linear time is also significantly positive, which implies the over-time growth in the public share is not fully explained by conventional welfare state predictors.

The second model omits all conventional welfare state predictors and only includes the 1960 value. In model 2, the 1960 value has a highly significant and large positive coefficient. For a standard deviation increase in the 1960 value, the current public share is expected to increase by 0.8 standard deviations. Equally notable, model 2 fits the data nearly as well as model $1\left(R^{2}=0.607\right.$ vs. 0.696), even though model 2 includes only one variable while model 1 includes fifteen. Model 2 strongly supports H1.

Model 3 includes both the 1960 value and the conventional welfare state predictors. Even adjusting for all fifteen variables, the 1960 value remains highly significantly positive. The coefficient attenuates somewhat, which suggests that some of the influence of the 1960 value is mediated by conventional welfare state predictors. Still, for a standard deviation increase in the 1960 value, the current public share is expected to increase by about 0.56 standard deviations. This is the largest coefficient in the model by a sizable margin. Thus, the third model also provides strong support for $\mathrm{H} 1 .^{7}$

The inclusion of the 1960 value in model 3 also alters the coefficients of several conventional welfare state predictors. Among power resources variables, voter turnout remains significantly positive. However, its

7. A logical next step is to interact the 1960 value with time as it is plausible that the effect of the 1960 value is stronger in earlier years and decays over time (Page 2006). In table 3, we interact the 1960 value with all independent variables. In that model, the interaction of the 1960 value and time is not significant $(z=-0.4)$. However, we also experimented with only interacting the 1960 value with time. Though the interaction is significantly negative, the effects of the 1960 value and time remain significantly positive. 
Table 1 OLS-PCSE Models of the Public Share of Health Spending in Eighteen Rich Democracies, 1961-2010. $(N=808)$ : Standardized Coefficients and $t$-scores

\begin{tabular}{|c|c|c|c|c|c|}
\hline & Model 1 & Model 2 & Model 3 & Model 4 & Model 5 \\
\hline \multirow[t]{2}{*}{1960 value } & & $.802 * * *$ & $.555 * * *$ & $.032 * *$ & $.213 * * *$ \\
\hline & & $(14.50)$ & $(11.32)$ & $(3.29)$ & $(4.66)$ \\
\hline \multirow[t]{2}{*}{ Right cabinet } & $-.092 * *$ & & $-.142 * * *$ & -.016 & $-.150 * * *$ \\
\hline & $(-2.64)$ & & $(-4.25)$ & $(-1.90)$ & $(-5.33)$ \\
\hline \multirow[t]{2}{*}{ Left cabinet } & -.050 & & $-.113 * *$ & -.010 & $-.149 * * *$ \\
\hline & $(-1.40)$ & & $(-3.18)$ & $(-1.03)$ & $(-4.93)$ \\
\hline \multirow[t]{2}{*}{ Unionization } & $.104 *$ & & .023 & -.017 & -.032 \\
\hline & $(2.53)$ & & $(.56)$ & $(-1.87)$ & $(-1.01)$ \\
\hline \multirow[t]{2}{*}{ Voter turnout } & $.141 * * *$ & & $.097 * *$ & $.021 *$ & -.012 \\
\hline & $(4.05)$ & & $(2.90)$ & $(2.34)$ & $(-.42)$ \\
\hline \multirow[t]{2}{*}{ Veto points } & $-.509 * * *$ & & $-.286 * * *$ & $-.042 * *$ & $-.127 * *$ \\
\hline & $(-9.82)$ & & $(-5.24)$ & $(-3.06)$ & $(-2.66)$ \\
\hline \multirow[t]{2}{*}{ Military spending } & -.017 & & -.025 & -.003 & -.034 \\
\hline & $(-.56)$ & & $(-.84)$ & $(-.37)$ & $(-1.27)$ \\
\hline \multirow[t]{2}{*}{ GDP pc } & -.112 & & -.008 & -.016 & .110 \\
\hline & $(-1.34)$ & & $(-.10)$ & $(-.71)$ & -1.58 \\
\hline \multirow[t]{2}{*}{ Deindustrialization } & $-.126^{*}$ & & .089 & .024 & -.011 \\
\hline & $(-2.09)$ & & $(1.44)$ & (1.57) & $(-.21)$ \\
\hline \multirow[t]{2}{*}{ Inflation } & $.042 * * *$ & & $.040 * * *$ & .003 & $.052 * * *$ \\
\hline & $(3.96)$ & & (3.69) & $(.49)$ & $(4.57)$ \\
\hline \multirow{2}{*}{ Unemployment } & -.004 & & -.040 & $-.033 * *$ & -.014 \\
\hline & $(-.15)$ & & $(-1.38)$ & $(-2.98)$ & $(-.52)$ \\
\hline \multirow[t]{2}{*}{ Trade openness } & $-.158 * * *$ & & $-.098 *$ & -.007 & $-.140 * * *$ \\
\hline & $(-3.43)$ & & $(-2.16)$ & $(-.72)$ & $(-3.90)$ \\
\hline \multirow[t]{2}{*}{ Population $>64$} & $.244 * * *$ & & $.150 * *$ & .012 & $.185^{* * *}$ \\
\hline & $(4.95)$ & & $(2.96)$ & $(1.05)$ & $(4.63)$ \\
\hline \multirow[t]{2}{*}{ Net migration } & -.002 & & -.004 & .001 & -.008 \\
\hline & $(-.22)$ & & $(-.39)$ & $(.08)$ & $(-.93)$ \\
\hline \multirow[t]{2}{*}{ Female labor } & .052 & & .027 & .005 & -.021 \\
\hline & $(1.29)$ & & (.67) & $(.44)$ & $(-.62)$ \\
\hline \multirow[t]{2}{*}{ Time } & $.322 * * *$ & & .082 & -.015 & .033 \\
\hline & $(3.36)$ & & $(.84)$ & $(-.66)$ & $(.41)$ \\
\hline Public share of health & & & & $.924 * * *$ & \\
\hline Spending $(t-1)$ & & & & $(78.02)$ & \\
\hline Public share of health & & & & & $.656^{* * *}$ \\
\hline Spending (country mean) & & & & & $(11.92)$ \\
\hline$R^{2}$ & .696 & .607 & .720 & .967 & .776 \\
\hline
\end{tabular}

Note: Constants not shown. All models employ a first-order autocorrelation correction. $* p<.05, * * p<.01, * * * p<.001$ 
coefficient is about two-thirds as large as in model 1. Unionization is now insignificant. Right cabinet remains significantly negative, however left cabinet becomes surprisingly significantly negative, and the coefficients for both increase considerably. Taking into account the 1960 value, centrist parties have encouraged the growth of the public share while both leftist and rightist parties have been associated with a declining public share. ${ }^{8}$ The key institutional variable, veto points remains significantly negative. However, the coefficient is about half as large as in model 1. Because veto points mostly differ between countries and do not change dramatically over time, this suggests that much of the influence of veto points manifested by 1960 . Still, veto points have independently slowed the growth of the public share since 1960. Among economic variables, inflation remains significantly positive, but deindustrialization is now insignificant and trade openness has a smaller significant positive coefficient. Population aging remains significantly positive, though it has a much smaller effect. Also, time is now insignificant. In sum, including the 1960 value has salient consequences for conventional welfare predictors.

Before moving forward, models 4-5 display two sensitivity analyses. As discussed above, $\mathrm{Y}_{1960}$ could be correlated with the lagged dependent variable (LDV). In model 4, we adjust for the LDV, which is very significantly positive $(t>78)$. However, even after adjusting for this powerful control, the 1960 value remains significantly positive $(t=3.3)$. This is the case even though right and left cabinet, inflation, trade openness, population $>64$, and time are insignificant. As discussed above, $\mathrm{Y}_{1960}$ could conflate initial conditions and unobserved time invariant country characteristics. While we cannot incorporate country FEs, model 5 adjusts for the country-mean of the dependent variable, which is also very significant and positive $(t=11.9)$. Again, however, the 1960 value remains significantly positive $(t=4.7)$. The magnitude of the coefficients of the 1960 value is naturally much smaller in models $4-5$. However, even adjusting for the LDV or the country-mean of the dependent

8. In other analyses, we estimated an OLS model predicting the 1960 value. We found cumulative left party power 1946-60 had a significant positive effect, and cumulative right party power 1946-1960 had a significant negative effect (before and after controlling for the significant negative effect of veto points) (cf. Huber and Stephens 2001). Thus, while left-right party power drove differences in the initial 1960 value, both parties are associated with a declining public share net of the 1960 value. Similarly, Reeves and colleagues (2014) find negative (albeit insignificant) effects of left and right party governments on per capita government health spending in twenty-seven European Union countries 1995-2011. As shown below (see table 3), this is complicated by the interaction between left cabinet and the 1960 value. 
variable, there continues to be a strong significant association with the 1960 value.

As an additional robustness check, we experimented with incorporating health care regimes in analyses available upon request (Beckfield, Olafsdottir, and Sosnaud 2013; Wendt 2009). Reestimating model 3, the analyses reveal that indicators for health care regimes do significantly influence the public share (e.g., adding a dummy for national health service; or dummies for "universal coverage-controlled access" and "low budget-restricted access" in reference to "health service provisionoriented" [Wendt 2009]). Further, there is evidence that health care regimes significantly interact with the 1960 value. Nevertheless, in every model, the main effect of the 1960 value remains highly significantly positive. Therefore, even though health care regimes meaningfully shape the public share and how the 1960 value influences the contemporary public share, the 1960 value maintains a robust impact on the public share.

\section{ISSP Analyses}

Table 1 supports $\mathrm{H} 1$ and demonstrates path dependency between the initial 1960 levels and current levels of the public share. To deepen understanding of this path dependency, we now evaluate $\mathrm{H} 2$ by investigating public opinion as one potential mechanism. We utilize the 2006 ISSP role of government survey, which includes data for fifteen of the eighteen countries (data is unavailable for Austria, Belgium, and Italy) (ISSP 2008). We analyze individual-level preferences for government spending on health as a function of the 1960 value and other variables. The dependent variable is a binary measure of preferring the same or greater spending (reference: spend less). Following prior research on welfare attitudes (Brooks and Manza 2007; Fernandez and Jaime-Castillo 2013; Kikuzawa, Olafsdottir, and Pescosolido 2008; Lynch and Gollust 2010; Svallfors 2007), we include a variety of individual-level variables. We also adjust for 2006 public health spending as a percent of GDP, which Kikuzawa, Olafsdottir, and Pescosolido (2008) find has a significant negative effect in a similar analysis. Plausibly, this is because rising health expenditures heighten fiscal pressures and anxieties about government budgets (Hacker 2004: 704). Because of the clustering of individuals within countries and the inclusion of country-level variables, we estimate logistic regression 
376 Journal of Health Politics, Policy and Law

Table 2 Logistic Regression Model of Individual Preference for the Same or Greater Government Spending on Health in 2006 in Fifteen Rich Democracies. $(N=17,373)$ : Standardized Average Marginal Effects or Average Marginal Effects and (Z-Scores)

\begin{tabular}{|c|c|c|c|}
\hline & Model 1 & Model 2 & Model 3 \\
\hline 1960 public share & $\begin{array}{l}.011 * \\
(2.42)\end{array}$ & $\begin{array}{l}.012 * \\
(2.39)\end{array}$ & $\begin{array}{l}.014 * \\
(2.59)\end{array}$ \\
\hline $\begin{array}{l}\text { Public health spending as } \\
\% \text { of GDP }\end{array}$ & & & $\begin{array}{l}-.016 * * \\
(-3.47)\end{array}$ \\
\hline Age & & $\begin{array}{l}.003 \\
(.23)\end{array}$ & $\begin{array}{l}.006 \\
(.48)\end{array}$ \\
\hline $\mathrm{Age}^{2}$ & & $\begin{array}{l}-.003 \\
(-.29)\end{array}$ & $\begin{array}{c}-.006 \\
(-.65)\end{array}$ \\
\hline Female & & $\begin{array}{l}.008 * * \\
(2.69)\end{array}$ & $\begin{array}{l}.007 * \\
(2.24)\end{array}$ \\
\hline Never married & & $\begin{array}{c}-.004 \\
(-.49)\end{array}$ & $\begin{array}{l}-.005 \\
(-.53)\end{array}$ \\
\hline Divorced & & $\begin{array}{l}-.010 \\
(-1.72)\end{array}$ & $\begin{array}{c}-.007 \\
(-1.21)\end{array}$ \\
\hline Widowed & & $\begin{array}{c}-.008 \\
(-1.32)\end{array}$ & $\begin{array}{c}-.006 \\
(-1.01)\end{array}$ \\
\hline Children in $\mathrm{HH}$ & & $\begin{array}{l}.001 \\
(.10)\end{array}$ & $\begin{array}{l}.001 \\
(.17)\end{array}$ \\
\hline Rural & & $\begin{array}{l}-.016 \\
(-1.61)\end{array}$ & $\begin{array}{c}-.017 \\
(-1.50)\end{array}$ \\
\hline Suburb & & $\begin{array}{l}-.003 \\
(-.55)\end{array}$ & $\begin{array}{l}-.005 \\
(-.80)\end{array}$ \\
\hline Low education & & $\begin{array}{c}-.008 \\
(-1.38)\end{array}$ & $\begin{array}{l}-.004 \\
(-.76)\end{array}$ \\
\hline High education & & $\begin{array}{c}-.011 * \\
(-2.39)\end{array}$ & $\begin{array}{c}-.009 * \\
(-2.22)\end{array}$ \\
\hline Part-time & & $\begin{array}{l}.002 \\
(.56)\end{array}$ & $\begin{array}{l}-.0002 \\
(-.04)\end{array}$ \\
\hline Unemployed & & $\begin{array}{l}.005 \\
(.68)\end{array}$ & $\begin{array}{c}.008 \\
(1.39)\end{array}$ \\
\hline Not in labor force & & $\begin{array}{l}.004 \\
(.68)\end{array}$ & $\begin{array}{c}.005 \\
(1.28)\end{array}$ \\
\hline Self-employment & & $\begin{array}{c}-.010^{*} \\
(-1.99)\end{array}$ & $\begin{array}{l}-.012 * * \\
(-2.48)\end{array}$ \\
\hline Public employment & & $\begin{array}{l}.011 * \\
(2.68)\end{array}$ & $\begin{array}{l}.012 * \\
(2.52)\end{array}$ \\
\hline Relative income & & $\begin{array}{l}-.005^{* *} \\
(-2.83)\end{array}$ & $\begin{array}{l}-.005 * * \\
(-3.21)\end{array}$ \\
\hline
\end{tabular}


Table 2 (continued)

\begin{tabular}{|c|c|c|c|}
\hline & Model 1 & Model 2 & Model 3 \\
\hline Protestant & & $.015(1.47)$ & $.012(.99)$ \\
\hline Catholic & & $.005(.56)$ & $.005(.51)$ \\
\hline Other religion & & $-.00002(-.00)$ & $-.006(-.81)$ \\
\hline Religious attendance & & $\begin{array}{c}-.004 \\
(-1.30)\end{array}$ & $\begin{array}{c}-.005 \\
(-1.61)\end{array}$ \\
\hline
\end{tabular}

Notes: Constants not shown. For binary variables we report AMEs and otherwise we report standardized AMEs.

$* p<.05, * * p<.01, * * * p<.001$

models with robust-clustered errors. ${ }^{9}$ Table 2 displays the models of preferences for government spending on health. We report average marginal effects (AMEs) and standardized AMEs (for continuous variables) to enable comparison. The remaining measurement details are available in appendix B.

Consistent with $\mathrm{H} 2$, the first model shows the 1960 value is significantly positive. For a standard deviation higher 1960 value, the probability of preferring the same or greater government spending on health increases by 1.1 percent. While this might seem like a small effect, it is important to acknowledge the mean is quite high as most people support the same or greater government spending on health (see appendix B). The second model adds the individual-level variables. Consistent with prior research, being female or a public employee increases support for government spending on health. By contrast, having higher education, being self-employed, and higher incomes are associated with significantly less support.

Model 2 also shows the 1960 value is significantly positive. For a standard deviation increase in the 1960 value, the probability of preferring the same or greater government spending on health increases by 1.2 percent. By a slight margin, the 1960 value has the largest effect in the model. The standardized AME for the 1960 value is larger than the AME for being female, having higher education, being self-employed or a public employee, or a standard deviation increase in higher income.

Model 3 adds the 2006 public health spending as a percent of GDP, which is significantly negative (Kikuzawa, Olafsdottir, and Pescosolido

9. An alternative would be hierarchical generalized linear models. However, with only fifteen countries and two country-level variables, we do not have a sufficient number of level-2 units for such models (Stegmueller 2013). The limited number of countries also discourages us from testing for cross-level interactions. 
378

Journal of Health Politics, Policy and Law

Table 3 OLS-PCSE Model of the Public Share of Health Spending in Eighteen Rich Democracies, 1961-2010. $(N=808)$

\begin{tabular}{|c|c|c|}
\hline & Coefficient & (Z-Score) \\
\hline 1960 value & $.388 * * *$ & $(13.04)$ \\
\hline Right cabinet & $-.086 * * *$ & $(-6.67)$ \\
\hline Right cabinet* 1960 & .000 & $(.51)$ \\
\hline Left cabinet & $-.101 * * *$ & $(-6.21)$ \\
\hline Left cabinet* 1960 & $.003 * * *$ & $(2.78)$ \\
\hline Unionization & $.066 * * *$ & $(2.68)$ \\
\hline Unionization* 1960 & -.002 & $(-1.01)$ \\
\hline Voter turnout & $.055^{*}$ & $(1.78)$ \\
\hline Voter turnout* 1960 & .001 & $(.37)$ \\
\hline Veto points & $-.717 * *$ & $(-2.31)$ \\
\hline Veto points* 1960 & $.091 * * *$ & $(4.80)$ \\
\hline Military spending & $.893 * * *$ & $(3.30)$ \\
\hline Military spending* 1960 & $.058 * * *$ & $(5.22)$ \\
\hline GDP pc & .000 & $(.98)$ \\
\hline GDP pc* 1960 & -.000 & $(-1.16)$ \\
\hline Deindustrialization & $.229 * * *$ & $(2.60)$ \\
\hline Deindustrialization* 1960 & .003 & $(.65)$ \\
\hline Inflation & $.200 * * *$ & $(5.86)$ \\
\hline Inflation* 1960 & $-.010 * * *$ & $(-5.61)$ \\
\hline Unemployment rate & $-.185^{*}$ & $(-1.79)$ \\
\hline Unemployment rate* 1960 & $-.017 * * *$ & $(-3.18)$ \\
\hline Trade openness & $-.073 * * *$ & $(-4.46)$ \\
\hline Trade openness $* 1960$ & $.002 * *$ & $(2.57)$ \\
\hline Population $>64$ & $.680 * * *$ & $(3.64)$ \\
\hline Population $>64 * 1960$ & $-.048 * * *$ & $(-3.19)$ \\
\hline Net migration & -.028 & $(-.93)$ \\
\hline Net migration* 1960 & .001 & $(.66)$ \\
\hline Female labor & -.006 & $(-.13)$ \\
\hline Female labor* 1960 & $.006^{* *}$ & $(2.54)$ \\
\hline Time & .028 & $(.25)$ \\
\hline Time* 1960 & -.002 & $(-.36)$ \\
\hline$R^{2}$ & .797 & \\
\hline
\end{tabular}

Note: Constant not shown. The model employs a first-order autocorrelation correction. $* p<.05, * * p<.01, * * * p<.001$.

2008). The same individual-level variables from model 2 are significant again. The 1960 value has an even larger and more significant positive AME. For a standard deviation increase in the 1960 value, the probability of preferring the same or greater government spending on health increases 1.4 percent. This standardized AME is larger than any 
individual-level variable, and only slightly smaller than the negative AME of public health spending as a percent of GDP. All models confirm H2. A higher public share in 1960 increases individual preferences for the same or greater government spending on health in $2006 .{ }^{10}$

\section{Interaction Effects in Pooled Time Series}

To investigate the self-reinforcing $\mathrm{H} 3$ and the counteracting $\mathrm{H} 4$, we return to the pooled time series data. Table 3 displays a model that interacts the 1960 value with all the conventional welfare state predictors from table 1 . Eight of the interaction effects are statistically significant, suggesting that these independent variables have differing effects depending on the 1960 value of a given country. To interpret the interactions, we estimate marginal effects for the independent variable at each 1960 value.

Figure 5 displays these effects with 95 percent confidence intervals. We focus on the eight significant interaction effects, even though a few others exhibit some (albeit statistically insignificant) variation.

Five independent variables exhibit positive feedback effects, supporting H3. Left cabinet significantly positively interacts with the 1960 value. At low 1960 values like the United States, the Netherlands, and Switzerland, left cabinet has a significant negative effect on the public share of health spending. However, in high 1960 value countries like Denmark, Italy, and the UK, left cabinet does not significantly influence the public share. At low 1960 values, veto points have a significant negative effect on the public share. At high 1960 values, veto points have a significant positive effect on the public share. Similarly, military spending only has a significant negative effect on the public share at low 1960 values. At even moderate 1960 values, military spending begins to have a significant positive effect on the public share. In low 1960 value countries, trade openness undermines the public share. However, in high 1960 value countries, the effect of trade openness is not significantly different from zero. Finally, female labor force participation has a significant negative effect in low 1960 value countries but has a significant positive effect in high 1960 value countries.

Three independent variables exhibit negative feedback effects, supporting H4. In low 1960 value countries, inflation significantly increases the public share. However, in high 1960 value countries, inflation does not significantly influence the public share. Unemployment negatively

10. Because the analyses only include 14 countries, the results are less significant if we omit countries. For example, if we omit the United States from model 3, the AME estimate is still .014. However, the $p$-value is only 15 . 

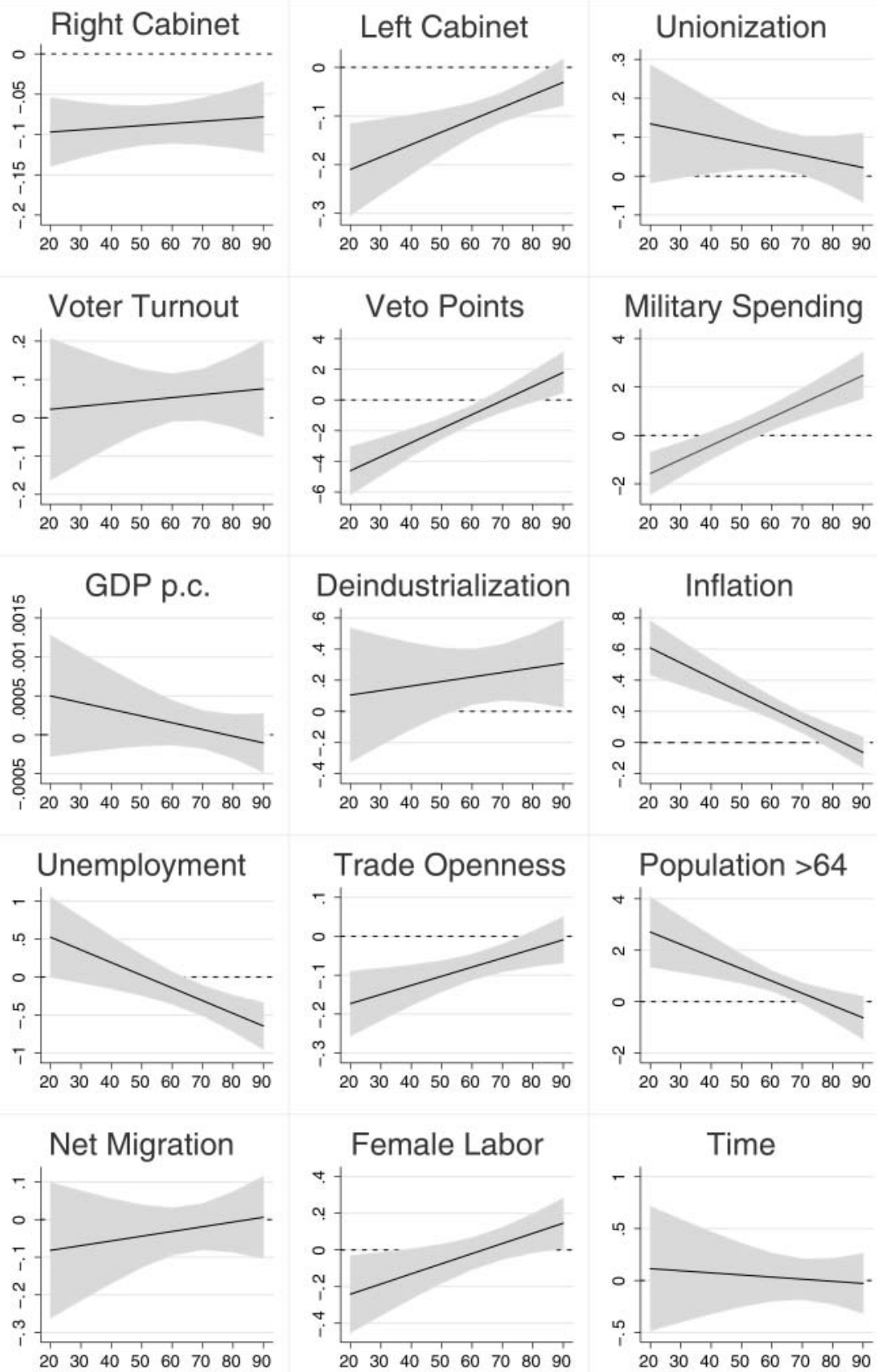

Figure 5 Marginal Effects of Independent Variables at Each 1960 Value

Notes: The $y$-axes depict coefficient for public share of health spending. The gray areas indicate $95 \%$ confidence intervals). 
interacts with the 1960 value. In low 1960 value countries, unemployment has a slight positive effect. However, at high 1960 values, unemployment has a significant negative effect. Finally, population aging has a significant positive effect in low 1960 value countries and a significant negative effect in high 1960 value countries.

Altogether, low 1960 value countries like the United States, the Netherlands, and Switzerland experience an increasing public share of health spending as a result of rising inflation, unemployment, and population aging. Because unemployment and aging have increased in most countries over time, this has likely contributed to the cross-national convergence observed in figure 3. Conversely, low 1960 value countries experience a declining public share as a result of left cabinet, veto points, military spending, trade openness, and female labor force participation. Because trade openness and female labor force participation have increased in most countries, this has slowed cross-national convergence. In high 1960 value countries like Denmark, Italy, and the UK, veto points, military spending, and (slightly) female labor force participation increase the public share, while only unemployment significantly reduces it. The rise of unemployment has pushed high 1960 value countries toward the cross-national mean, while the rise of female labor force participation has partially offset this pressure toward convergence.

\section{Discussion}

This study analyzes the cross-national and historical variation in the public share of health spending in rich democracies. We contend the public share is important for several reasons. The public share reflects meaningful institutional and policy differences in the organization and socialization of health care. The public share is also associated with health care costs, the organization of insurance, population health outcomes, and inequality. Public health care is one of the most expensive social policies and is often a source of political contention. Nevertheless, cross-national analyses remain relatively rare in the health policy literature and health care has been relatively neglected by the welfare state literature. We analyze pooled time series data on eighteen rich democracies from 1960 to 2010. We supplement this with analyses of the 2006 International Social Survey Programme (ISSP).

Building on path dependency theories, we examine four hypotheses. The first two hypotheses are affirmed. Initial levels of the public share in 1960 are very positively associated with 2010 levels, and the public share in 1960 significantly predicts individual preferences for the same or greater 
government spending in 2006. Indeed, most of the variation 1960-2010 in public health spending can be explained by a country's initial value in 1960 (see table 1, model 2). This 1960 value has large significant effects in models of 1961-2010. Further, the inclusion of the 1960 value alters the coefficients of conventional welfare state predictors. Notably, adjusting for the 1960 value reveals that both left and right cabinets were negatively associated with declines in the public share relative to centrist parties (see also fn. 9). Also, voter turnout, veto points, trade openness and population aging have much smaller effects once we adjust for the 1960 value, while unionization and deindustrialization become insignificant. This implies that conventional welfare state predictors may be conflated with stable differences between countries that had already manifested by 1960 . While FE models also adjust for stable differences between countries, our approach has the advantage that the 1960 value has theoretical content.

The 2006 ISSP analyses provide evidence of public opinion serving as a mechanism in the path dependency of the public share. Consistent with $\mathrm{H} 2$, higher initial 1960 values encourage norms and interests, which manifest in individual preferences for maintaining or increasing government spending on health care (Brooks and Manza 2007; Fernandez and Jaime-Castillo 2013; Jordan 2010). Notably, we demonstrate that the 1960 value has a standardized AME that is larger than established predictors of welfare attitudes such as being female, self-employed, or a public employee, or having a high education or income. On balance, it is important to acknowledge that most respondents in all countries favor the same or greater government spending on health (see appendix B). On one hand, this suggests that individual preferences may not be able to explain the substantial cross-national variation in the public share. On the other hand, the high levels of individual preferences make it much more difficult for the 1960 value to have a significant effect. That the 1960 value significantly predicts individual preferences forty-six years later suggests public opinion is one mechanism (among several) at work in path dependency.

To be clear, we do not provide evidence of a critical juncture, nor do we differentiate between stricter definitions of path dependency (see fn. 6; Jackson and Kollman 2012; Page 2006). Our contribution is to demonstrate the core general principle of path dependency as contained in $\mathrm{H} 1-\mathrm{H} 2$. It is important to acknowledge that the initial 1960 value of the public share stands in for a variety of important historical, political, and social phenomena. We contend the initial value captures the historic legacies of health politics and policies prior to 1960, and reflects enduring 
expectations about government's role in health care and the organization of health care in 1960 and before.

Beyond $\mathrm{H} 1$ and $\mathrm{H} 2$, we examine two processes for how initial conditions of social policy feed back into the contemporary politics of the policy. We present the self-reinforcing $\mathrm{H} 3$ expecting positive feedbacks, and the counteracting $\mathrm{H} 4$ expecting negative feedbacks. The analyses provide some support for each of these hypotheses. We show that the 1960 values interact significantly with eight conventional welfare state predictors. Most supportive of $\mathrm{H} 3$ are the effects of left cabinet, veto points, military spending, trade openness, and female labor force participation. Most supportive of $\mathrm{H} 4$ are the effects of inflation, unemployment, and population aging. Therefore, we find evidence of both self-reinforcing and counteracting processes, and these factors have both contributed to and offset the trend toward cross-national convergence. Because much more of the literature has concentrated on self-reinforcing processes and positive feedbacks, we encourage greater attention to counteracting processes and negative feedbacks.

The present study contributes to an emerging literature of cross-national analyses of the public share of health spending. We aim to build bridges between the case study literature on health care and the cross-national welfare state literature. Relative to other welfare state outcomes, we show that some conventional welfare state predictors have unexpected effects for this particular outcome of the public share of health spending. We also confirm a number of arguments from the small- $N$ and case study literature on health care policy. For instance, veto points are particularly important (Immergut 1992). More generally, we hope to demonstrate the value of dialogue between these literatures. Many case studies provide evidence consistent with path dependency and complementary to welfare state theories. At the same time, the health care literature suggests that health care does not simply mirror but gives us new insights on other welfare state outcomes (Bambra 2005).

This article also aims to build bridges between the largely qualitative path dependency literature and the quantitative welfare state literature. Our analytic strategy illustrates how path dependency can be applied in quantitative analyses, and this strategy could be useful for other studies. It would be worthwhile to investigate if the initial 1960 value explains other welfare programs like pensions and unemployment insurance as well as welfare effort generally. Given that time series data are available for most welfare state outcomes and the ISSP contains a variety of welfare attitudes, it could prove useful to incorporate historical values of social policy in analyses of 
contemporary welfare attitudes. If the 1960 value does not as effectively explain other welfare state outcomes or welfare attitudes, this raises the question of why there is so much path dependency for the public share of health spending and not for other social policies. This would then enable greater precision in understanding the conditions under which social policy is more or less path dependent (Hacker 2002).

Beyond the points already raised, we encourage future research in several directions. First, there is a need for greater investigation of the cross-national and historical variation in health care policy. Second, though we examine individual preferences as one mechanism of path dependency, there are obviously other mechanisms between the initial 1960 values and current levels of the public share. One could investigate the effects of the 1960 value on, for example, mediating factors such as physician or insurance power, voting, party manifestos, and coalitions between collective actors. Third, there has been increasing interest in the welfare states of developing and nondemocratic countries. For many such countries, data on social policies exist prior to democratization or even prior to the transition to authoritarianism that preceded democratization. It would be interesting to investigate the relationship between the historical legacies of the social policies of earlier regimes and the social policies that emerge and expand during and after democratization.

Finally, because we show that the 1960 value of the public share is important to contemporary health care politics and policy, the historical sources of health care policy continue to deserve attention. Just as scholars have investigated the role of institutions like taxation and corporatism in the late nineteenth century and early twentieth century for other welfare state outcomes, it is essential to understand the deeper historical origins of health care policies. Indeed, this article is one step toward integrating the historical studies of why countries adopted national health service, national health insurance, or neither (Navarro 1989) and quantitative studies of the contemporary welfare state. Relatedly, although we continue to find a significant effect of the 1960 value, sensitivity analyses suggest meaningful differences between health care regimes (and interactions between health care regimes and the 1960 value) that deserve further attention.

Public funding of health care has contributed to many improvements in health in recent decades. Despite the cross-national variation, there is a consensus that the state should play at least some role in health care. In many rich democracies, health care is even a social right. Markets remain unlikely to be able to provide health care for all because of the perennial 
uncertainties regarding health risks and the efficacy of treatments (Arrow 1963). Nevertheless, all rich democracies face increasingly older populations and longer life expectancies, and health care costs represent an increasingly expensive item in government budgets (Marmor et al. 2005). As a result, health care will continue to be one of the most important social policies and an ongoing source of political contention. Thus, understanding the politics of health care policy should remain quite important in the years to come.

David Brady is professor in the School of Public Policy at the University of California, Riverside. He is also director of the Blum Initiative on Global and Regional Poverty. From 2012 to 2015, he was director of the Inequality and Social Policy Department at the WZB Berlin Social Science Center. He studies poverty/inequality, social policy, political economy, and health/health care, among other topics. He is the author of Rich Democracies, Poor People, and coeditor of The Oxford Handbook of the Social Science of Poverty.

Susanne Marquardt is a research fellow at the WZB Berlin Social Science Center. Her research focuses on comparative welfare state policies, housing, and inequality. Currently, she is pursuing her PhD on the effects of changes in home ownership on welfare states. She is also a research assistant in a collaborative project with the Institute for Public Policy Research (IPPR) in London and Aston University in Birmingham which compares housing policies in Germany and the UK.

Gordon Gauchat is assistant professor of Sociology at the University of WisconsinMilwaukee. His research focuses on the interaction of public perceptions of science and political and cultural cleavages in the United States and Europe. He has published research in American Sociological Review, Social Forces, Gender and Society and Public Understanding of Science. His current work examines public perceptions of medical doctors' and climate scientists' legitimacy to influence political policy.

Megan M. Reynolds is assistant professor in the Department of Sociology at the University of Utah. Her work examines health and health inequalities in order to understand processes of stratification and their consequences. She is particularly interested in the role of power and politics in influencing population health and in how gender and ethnicity condition the health of various immigrant groups. She has published work in Social Forces, the Journal of Health and Social Behavior, and Gender in Management. She holds an MA in applied sociology from the University of Massachusetts Boston and a PhD in sociology from Duke University. 


\section{References}

Anderson, Gerard F., Uwe E. Reinhardt, Peter S. Hussey, and Varduhi Petrosyan. 2003. "It's the Prices Stupid: Why the United States Is So Different from Other Countries." Health Affairs 22, no. 3: 89-105.

Arrow, Kenneth J. 1963. "Uncertainty and the Welfare Economics of Medical Care." American Economic Review 53, no. 5: 941-73.

Bambra, Clare. 2005. "Worlds of Welfare and the Health Care Discrepancy." Social Policy and Society 4, no. 1: 31-41.

Bambra, Clare, Debbie Fox, and Alex Scott-Samuel. 2005. "Towards a Politics of Health.” Health Promotion International 20, no. 2: 187-193.

Beckfield, Jason, and Nancy Krieger. 2009. "Epi + Demos + Cracy: Linking Political Systems and Priorities to the Magnitude of Health Inequities-Evidence, Gaps, and a Research Agenda." Epidemiological Reviews 31, no. 1: 152-77.

Beckfield, Jason, Sigrun Olafsdottir, and Benjamin Sosnaud. 2013. "Healthcare Systems in Comparative Perspective: Classification, Convergence, Institutions, Inequalities, and Five Missed Turns." Annual Review of Sociology 39:127-46.

Béland, Daniel. 2010. "Policy Change and Health Care Research." Journal of Health Politics, Policy and Law 35, no. 4: 615-41.

Bevan, Gwyn, Jan-Kees Helderman, and David Wilsford. 2010. "Changing Choices in Health Care: Implications for Equity, Efficiency, and Cost." Health Economics, Policy and Law 5, special issue no. 3: 251-67.

Bevan, Gwyn, and Ray Robinson. 2005. "The Interplay between Economic and Political Logics: Path Dependency in Health Care in England." Journal of Health Politics, Policy and Law 30, nos. 1-2: 53-78.

Blake, Charles H., and Jessica R. Adolino. 2001. "The Enactment of National Health Insurance: A Boolean Analysis of Twenty Advanced Industrial Countries.” Journal of Health Politics, Policy and Law 26, no. 4: 679-708.

Brady, David. 2009. Rich Democracies, Poor People: How Politics Explain Poverty. New York: Oxford University Press.

Brady, David, and Amie Bostic. 2015. "Paradoxes of Social Policy: Welfare Transfers, Relative Poverty and Redistribution Preferences." American Sociological Review 80, no. 2: 268-98.

Brady, David, Evelyne Huber, and John D. Stephens. 2014. Comparative Welfare States Data Set. University of North Carolina and WZB Berlin Social Science Center.

Brady, David, and Hang Young Lee. 2014. "The Rise and Fall of Government Spending in Affluent Democracies, 1971-2008." Journal of European Social Policy 24, no. 1: 56-79.

Brooks, Clem, and Jeff Manza. 2007. Why Welfare States Persist: The Importance of Public Opinion in Democracies. Chicago: University of Chicago Press.

Campbell, Andrea Louise. 2011. "Policy Feedbacks and the Impact of Policy Designs on Public Opinion.” Journal of Health Politics, Policy and Law 36, no. 6: 961-73. 
Chung, Haejoo, and Carles Muntaner. 2006. "Political and Welfare State Determinants of Infant and Child Health Indicators: An Analysis of Wealthy Countries." Social Science and Medicine 63, no. 3: 829-42.

Daschle, Thomas, Scott S. Greenberger, and Jeanne M. Lambrew. 2008. Critical: What We Can Do about the Health-Care Crisis. New York: Thomas Dunne Books.

Dutton, Paul V. 2007. Differential Diagnoses: A Comparative History of Health Care Problems and Solutions in the United States and France. Ithaca, NY: Cornell University Press.

Esarey, Justin, and Jacqueline H. R. DeMeritt. 2014. "Defining and Modeling StateDependent Dynamic Systems.” Political Analysis 22, no. 1: 61-85.

Fernandez, Juan J., and Antonio M. Jaime-Castillo. 2013. "Positive or Negative Policy Feedbacks? Explaining Popular Attitudes towards Pragmatic Pension Policy Reforms." European Sociological Review 29, no. 4: 803-15.

Flora, Peter. 1986. Growth to Limits: The Western European Welfare States since World War II, Volume 1. Berlin: de Gruyter.

Hacker, Jacob. 2002. The Divided Welfare State: The Battle over Public and Private Social Benefits in the United States. New York: Cambridge University Press.

Hacker, Jacob. 2004. "Review Article: Dismantling the Health Care State? Political Institutions, Public Policies, and the Comparative Politics of Health Reform." British Journal of Political Science 34, no. 4: 693-724.

Hicks, Alexander. 1999. Social Democracy and Welfare Capitalism: A Century of Income Security Politics. Ithaca, NY: Cornell University Press.

Huber, Evelyne, and John D. Stephens. 2001. Development and Crisis of the Welfare State Chicago: University of Chicago Press.

Huber, Evelyne, and John D. Stephens. 2012. Democracy and the Left: Social Policy and Inequality in Latin America. Chicago: University of Chicago Press.

Immergut, Ellen. 1992. Health Politics: Interests and Institutions in Western Europe. New York: Cambridge University Press.

ISSP Research Group. 2008. International Social Survey Programme: Role of Government IV-ISSP 2006. GESIS Data Archive, Cologne. ZA4700 data file.

Jacobs, Lawrence R., and Theda Skocpol. 2012. Health Care Reform and American Politics: What Everyone Needs to Know. New York: Oxford University Press.

Jackson, John E., and Ken Kollman. 2012. "Modeling, Measuring, and Distinguishing Path Dependence, Outcome Dependence, and Outcome Independence.” Political Analysis 20, no. 2: 157-74.

Jensen, Carsten. 2011. "Marketization via Compensation: Health Care and the Politics of the Right in Advanced Industrialized Nations." British Journal of Political Science 41, no. 4: 907-26.

Jordan, Jason. 2010. "Institutional Feedback and Support for the Welfare State: The Case of National Health Care." Comparative Political Studies 43, no. 7: 862-85.

Jordan, Jason. 2011. "Health Care Politics in the Age of Retrenchment." Journal of Social Policy 40, no. 1: 113-34.

Kikuzawa, Saeko, Sigrun Olafsdottir, and Bernice A. Pescosolido. 2008. "Similar Pressures, Different Contexts: Public Attitudes toward Government Intervention 
for Health Care in Twenty-One Nations." Journal of Health and Social Behavior 49, no. 4: 385-99.

Kittel, Bernhard, and Herbert Obinger. 2003. "Political Parties, Institutions, and the Dynamics of Social Expenditure in Times of Austerity." Journal of European Public Policy 10, no. 1: 20-45.

Korpi, Walter, and Joakim Palme. 1998. "The Paradox of Redistribution and Strategies of Equality: Welfare State Institutions, Inequality, and Poverty in the Western Countries." American Sociological Review 63, no. 5: 661-87.

Laugesen, Miriam J., and Sherry A. Glied. 2011. "Higher Fees Paid to U.S. Physicians Drive Higher Spending for Physician Services Compared to Other Countries." Health Affairs 30, no. 9: 1647-56.

Lynch, Julia, and Sarah E. Gollust. 2010. "Playing Fair: Fairness Beliefs and Health Policy Preferences in the United States." Journal of Health Politics, Policy and Law 35, no. 6: 849-87.

Maarse, Hans. 2006. "The Privatization of Health Care in Europe: An Eight-Country Analysis." Journal of Health Politics, Policy and Law 31, no. 5: 981-1014.

Mahoney, James. 2000. "Path Dependence in Historical Sociology." Theory and Society 29, no. 4: 507-48.

Marmor, Ted, Richard Freeman, and Kieke Okma. 2005. "Comparative Perspectives and Policy Learning in the World of Health Care." Journal of Comparative Policy Analysis 7, no. 4: 331-48.

Montanari, Ingalill, and Kenneth Nelson. 2014. "Health Care Determinants in Comparative Perspective: The Role of Partisan Politics for Health Care Provision." International Journal of Comparative Sociology 54, nos. 5-6: 445-66.

Moran, Michael. 2000. "Understanding the Welfare State: The Case of Healthcare." British Journal of Politics and International Relations 2, no. 2: 135-160.

Morgan, Kimberly J., and Andrea Louise Campbell. 2011. The Delegated Welfare State. New York: Oxford University Press.

Navarro, Vicente. 1989. "Why Some Countries Have National Health Insurance, Others Have National Health Services, and the U.S. Have [sic] Neither." Social Science and Medicine 28, no. 3: 887-98.

Navarro, Vicente, Carles Muntaner, Carme Borrell, Joan Benach, Águeda Quiroga, Maica Rodríguez-Sanz, Núria Vergés, and M. Isabel Pasarín. 2006. "Politics and Health Outcomes." Lancet 368, no. 9540: 1033-37.

Navarro, Vicente, and Leiyu Shi. 2001. "The Political Context of Social Inequalities and Health." Social Science and Medicine 52, no. 1: 481-91.

Nixon, John. 1999. "Convergence Analysis of Health Care Expenditure in the EU Countries Using Two Approaches”. Discussion Paper in Economics, 1999/ 03. York: University of York.

North, Douglass C. 1990. Institutions, Institutional Change and Economic Performance. New York: Cambridge University Press.

Oberlander, Jonathan. 2003. "The Politics of Health Reform: Why Do Bad Things Happen to Good Plans?" Health Affairs (web exclusive) W3: 391-404.

OECD. (Organisation for Economic Co-operation and Development). 2012. Health Data: Definitions, Sources and Methods, Health Expenditure and Financing. 
www.oecd.org/els/health-systems/Table-of-Content-Metadata-OECD-Health -Statistics-2013.pdf (accessed March 13, 2014).

Okma, Kieke G. H., Tsung-mei Cheng, David Chinitz, Luca Crivelli, Meng-kim Lim, Hans Maarse, and Maria Eliana Labra. 2010. "Six Countries, Six Health Reform Models? Health Care Reform in Chile, Israel, Singapore, Switzerland, Taiwan, and the Netherlands." Journal of Comparative Policy Analysis 12, nos. 1-2: 75-113.

Olafsdottir, Sigrun, and Jason Beckfield. 2011. "Health and the Social Rights of Citizenship: Integrating Welfare State Theory and Medical Sociology." In Handbook of the Sociology of Health, Illness and Healing, edited by Bernice A. Pescosolido, Jack K. Martin, Jane D. McLeod, and Anne Rogers, 101-15. New York: Springer.

Page, Scott E. 2006. "Path Dependence.” Quarterly Journal of Political Science 1, no. 1: 87-115.

Pierson, Paul. 2001. "Coping with Permanent Austerity: Welfare State Restructuring in Affluent Democracies." In The New Politics of the Welfare State, edited by Paul Pierson, 410-56. New York: Oxford University Press.

Pierson, Paul. 2004. Politics in Time: History, Institutions, and Social Analysis. Princeton, NJ: Princeton University Press.

Quadagno, Jill. 2005. One Nation Uninsured: Why the US Has No National Health Insurance. New York: Oxford University Press.

Reeves, Aaron, Martin McKee, Sanjay Basu, and David Stuckler. 2014. "The Political Economy of Austerity and Healthcare: Cross-National Analysis of Expenditure Changes in Twenty-Seven European Nations 1995-2011." Health Policy 115, no. 1: $1-8$.

Reinhardt, Uwe E., Peter S. Hussey, and Gerard F. Anderson. 2004. "US Health Care Spending in an International Context." Health Affairs 23, no. 3: 10-25.

Rochaix, Lise, and David Wilsford. 2005. "State Autonomy, Policy Paralysis: Paradoxes of Institutions and Culture in the French Health Care System." Journal of Health Politics, Policy and Law 30, nos. 1-2: 97-120.

Rose, Richard, and Paul Davies. 1994. Inheritance in Public Policy: Change without Choice in Britain. New Haven, CT: Yale University Press.

Skocpol, Theda. 1992. Protecting Soldiers and Mothers: The Political Origins of Social Policy in the United States. Cambridge, MA: Harvard University Press.

Skocpol, Theda. 1996. Boomerang: Clinton's Health Security Effort and the Turn against Government in US Politics. New York: Norton.

Starr, Paul. 1982. The Social Transformation of American Medicine. New York: Basic Books.

Stegmueller, Daniel. 2013. "How Many Countries for Multilevel Modeling? A Comparison of Frequentist and Bayesian Approaches." American Journal of Political Science 57, no. 3: 748-61.

Steinmo, Sven, and Jon Watts. 1995. "It's the Institutions Stupid! Why Comprehensive National Health Insurance Always Fails in America." Journal of Health Politics, Policy and Law 20, no. 2: 329-72.

Stinchcombe, Arthur. 1968. Constructing Social Theories. New York: Harcourt, Brace. 


\section{0}

Journal of Health Politics, Policy and Law

Svallfors, Stefan. 2007. The Political Sociology of the Welfare State. Stanford, CA: Stanford University Press.

Swank, Duane. 2002. Global Capital, Political Institutions, and Policy Change in Developed Welfare States. New York: Cambridge University Press.

Thelen, Kathleen. 2004. How Institutions Evolve: The Political Economy of Skills in Germany, Britain, the United States, and Japan. New York: Cambridge University Press.

Tuohy, Carolyn Hughes, Colleen M. Flood, and Mark Stabile. 2004. "How Does Private Finance Affect Public Health Care Systems? Marshalling the Evidence from OECD Nations." Journal of Health Politics, Policy and Law 29, no. 3: 359-96.

Vrangbaek, Karsten, and Terkel Christiansen. 2005. "Health Policy in Denmark: Leaving the Decentralized Welfare Path?" Journal of Health Politics, Policy and Law 30, nos. 1-2: 29-52.

Weaver, Kent. 2010. "Paths and Forks or Chutes and Ladders? Negative Feedbacks and Policy Regime Change.” Journal of Public Policy 30, no. 2: 137-62.

Wendt, Claus. 2009. "Mapping European Healthcare Systems: A Comparative Analysis of Financing, Service Provision and Access to Healthcare." Journal of European Social Policy 19, no. 5: 432-45.

Wendt, Claus. 2015. "Healthcare Policies and Finance." In The Palgrave International Handbook of Healthcare Policy and Governance, edited by E. Kuhlmann, R. H. Blank, I. L. Bourgeault, and C. Wendt, 54-69. London: Palgrave Macmillan.

Wilensky, Harold L. 2002. Rich Democracies: Political Economy, Public Policy, and Performance. Berkeley: University of California Press.

Wilkerson, John D. 2003. "The Political Economy of Health in the United States." Annual Review of Political Science 6:327-43.

Wilsford, David. 1994. "Path Dependency, or Why History Makes It Difficult but Not Impossible to Reform Health Care Systems in a Big Way." Journal of Public Policy 14, no. 3: 251-83.

Wilsford, David. 1995. "States Facing Interests: Struggles Over Health Care Policy in Advanced, Industrial Democracies." Journal of Health Politics, Policy and Law 20, no. 3: 571-613. 
Appendix A Descriptive Statistics and Sources for Variables in Pooled Time Series Analysis $(N=808)$

\begin{tabular}{|c|c|c|c|}
\hline & Mean & SD & Source(s) \\
\hline $\begin{array}{l}\text { Public share of } \\
\text { health spending }\end{array}$ & 73.757 & 12.677 & OECD, Health Data \\
\hline 1960 value & 62.305 & 18.392 & Same \\
\hline Right cabinet & 39.732 & 31.314 & Brady et al. (2014) \\
\hline Left cabinet & 32.261 & 29.096 & Same \\
\hline Unionization & 42.253 & 18.532 & $\begin{array}{l}\text { Visser, Jelle, ICTWSS (v } 3.0 \\
\text { and v 4.0), www.uva- } \\
\text { aias.net/207 }\end{array}$ \\
\hline Voter turnout & 78.615 & 12.615 & Brady et al. (2014) \\
\hline Veto points & 2.830 & 2.092 & Same \\
\hline Military spending & 2.524 & 1.426 & $\begin{array}{l}\text { Sipri, Military Expenditure } \\
\text { Database, www.sipri.org/ } \\
\text { research/armaments/milex/ }\end{array}$ \\
\hline GDP p.c. & 23391.420 & 7626.689 & Penn World Tables \\
\hline Deind. & 61.991 & 10.630 & $\begin{array}{l}\text { OECD, Employment and } \\
\text { Labour Force Statistics }\end{array}$ \\
\hline Inflation & 4.949 & 4.065 & $\begin{array}{l}\text { OECD, Main Economic } \\
\text { Indicators }\end{array}$ \\
\hline Unemployment & 5.305 & 3.526 & $\begin{array}{l}\text { OECD, Employment and } \\
\text { Labour Force Statistics }\end{array}$ \\
\hline Trade openness & 48.496 & 28.185 & $\begin{array}{l}\text { IMF, International Financial } \\
\text { Statistics }\end{array}$ \\
\hline Population $>64$ & 13.004 & 2.683 & $\begin{array}{l}\text { OECD, Employment and } \\
\text { Labour Force Statistics }\end{array}$ \\
\hline Net migration & 2.024 & 3.804 & $\begin{array}{l}\text { OECD, Health Data; OECD, } \\
\text { Employment and Labour } \\
\text { Force Statistics }\end{array}$ \\
\hline Female labor & 56.439 & 12.461 & $\begin{array}{l}\text { OECD, Employment and } \\
\text { Labour Force Statistics }\end{array}$ \\
\hline Time & 23.853 & 13.105 & \\
\hline
\end{tabular}

Note: The proximate source for most variables is Brady et al. (2014). 
392 Journal of Health Politics, Policy and Law

Appendix B Descriptive Statistics and Details for Variables in ISSP Analysis $(N=17,373)$

\begin{tabular}{|c|c|c|c|}
\hline & Mean & SD & Reference Group \\
\hline $\begin{array}{c}\text { Preference for same or } \\
\text { greater government } \\
\text { spending on health }\end{array}$ & .966 & .180 & Prefer less or much less \\
\hline Age & 48.782 & 16.595 & \\
\hline $\mathrm{Age}^{2}$ & 2655.038 & 1677.295 & \\
\hline Female & .523 & .499 & Male \\
\hline Never married & .230 & .421 & Married \\
\hline Divorced & .103 & .305 & Married \\
\hline Widowed & .061 & .239 & Married \\
\hline Children in $\mathrm{HH}$ & .332 & .471 & No children \\
\hline Rural & .281 & .449 & Urban \\
\hline Suburb & .495 & .500 & Urban \\
\hline Low education & .364 & .481 & Medium education \\
\hline High education & .204 & .403 & Medium education \\
\hline Part-time & .133 & .339 & Full-time employee \\
\hline Unemployed & .031 & .173 & Full-time employee \\
\hline Not in labor force & .354 & .478 & Full-time employee \\
\hline Self-employment & .111 & .314 & Not self-employed \\
\hline Public employment & .270 & .444 & Private sector \\
\hline Relative income & .019 & 1.008 & \\
\hline Protestant & .411 & .492 & No religion \\
\hline Catholic & .222 & .416 & No religion \\
\hline Other religion & .099 & .298 & No religion \\
\hline Religious attendance & 2.162 & 2.077 & \\
\hline
\end{tabular}

